(c) The Author(s), 2021. Published by Cambridge University Press. This is an Open Access article, distributed under the terms of the Creative Commons Attribution licence (http://creativecommons.org/licenses/by/4.0/), which permits unrestricted re-use, distribution, and reproduction in any medium, provided the original work is properly cited. 0361-6843/21 doi: $10.1017 /$ S1352325221000033

\title{
A DEFENSE OF HUMEAN PROPERTY THEORY
}

\author{
Ira K. Lindsay* \\ University of Surrey, School of Law, Guildford, \\ United Kingdom
}

\begin{abstract}
Two rival approaches to property rights dominate contemporary political philosophy: Lockean natural rights and egalitarian theories of distributive justice. This article defends a third approach, which can be traced to the work of David Hume. Unlike Lockean rights, Humean property rights are not grounded in pre-institutional moral entitlements. In contrast to the egalitarian approach, which begins with highly abstract principles of distributive justice, Humean theory starts with simple property conventions and shows how more complex institutions can be justified against a background of settled property rights. Property rights allow people to coordinate their use of scarce resources. For property rules to serve this function effectively, certain questions must be considered settled. Treating existing property entitlements as having prima facie validity facilitates cooperation between people who disagree about distributive justice. Lockean and egalitarian theories endorse moral claims that threaten to unsettle property conventions and undermine social cooperation.
\end{abstract}

Two rival approaches to property rights predominate in contemporary political philosophy. The first appeals to Lockean natural rights. ${ }^{1}$ The second family of theories, which I will call "resource egalitarian," analyzes property entitlements in light of egalitarian principles of distributive justice. ${ }^{2}$ This

* The author would like to thank Peter Railton, Elizabeth Anderson, Allan Gibbard, Scott Hershovitz, Sarah Buss, Don Loeb, Bart Wilson, Gabe Mendlow, Jules Coleman, David Plunkett, Julie Rose, David Owens, Ken Ehrenberg, two anonymous reviewers for Legal Theory, and participants in the University of Vermont \& Dartmouth College Philosophy Colloquium and the University of Surrey Centre for Law and Philosophy Mini-Colloquium on Property Rights. The author also wishes to acknowledge the research assistance of Benita R. Mathew.

1. E.g., Robert Nozick, Anarchy, State, and Utopia (1974); Eric Mack, The Natural Right of Property, 27 Soc. Phil. \& Pol'y 53 (2010); Loren Lomasky, Persons, Rights, and the Moral Community (1987).

2. Although the work of John Rawls is largely responsible for framing the resource egalitarian research agenda, Ronald Dworkin might be a better example of an archetypal resource 
article defends a third approach, which is derived from the work of David Hume. ${ }^{3}$ Humeans join resource egalitarians in rejecting natural rights as a source of pre-institutional property entitlements. However, in contrast to the resource egalitarian approach, which starts with highly abstract principles of distributive justice and analyzes particular property rules in light of these principles, Humean theory begins with simple property conventions and shows how more complex institutions can be justified against a background of settled property rights. Property rights allow people to coordinate their actions with respect to scarce resources. For property rules to serve this function effectively, certain questions must be considered settled. Neo-Lockean and resource egalitarian theories, by contrast, endorse moral claims that threaten to unsettle conventional property rights and thus undermine social cooperation. In this article, I will describe Humean property theory, explore how it might be situated in a broader moral and political theory, and explain its advantages over its rivals. Hume's theory of justice is sometimes criticized as insufficient to justify strong moral entitlements or as unduly conservative in its implications. In response to the former objection, I argue that Humean theory grounds properly moral rights. In response to the latter, I show how Humean property theory is compatible with modern liberal as well as modern conservative policy preferences.

\section{NEO-LOCKEAN AND RESOURCE EGALITARIAN THEORIES}

Since it is easier to explain what is distinctive about Humean theories of property in contrast to their main rivals, I will start by describing the neo-Lockean and resource egalitarian approaches. ${ }^{4}$ My account will focus on the broad commonalities shared by each family of views without exploring their numerous permutations. Discussions of property rights in political

egalitarian since his theory of distributive justice follows more directly from a conception of moral equality. See Ronald Dworkin, What Is Equality? Part 2: Equality of Resources, 10 PHIL. \& Pub. Aff. 283 (1981).

3. Hume's account of property rights has received less attention than Locke's or that of the resource egalitarians. Exceptions include Jeremy Waldron, Brian Barry, and Jerry Gaus. See Jeremy Waldron, 'To Bestow Stability upon Possession': Hume's Alternative to Locke, in Philosophical Foundations of Property LaW 1-12 (James E. Penner \& Henry E. Smith eds., 2013); Jeremy Waldron, The Advantages and Difficulties of the Humean Theory of Property, 11 Soc. Phil. \& Pol'y 85 (1994) [hereinafter Waldron, The Advantages and Difficulties of the Humean Theory of Property]; Brian Barry, A Treatise on Social Justice, Volume I: Theories of Justice (1989); Gerald Gaus, The Order of Public Reason: A Theory of Freedom and Morality in a Diverse AND Bounded WORLd (2011).

4. A fourth approach to property theory, Kantian property theory, has a more ambiguous relationship to Humean property theory. Kant's theory of property is grounded in a political theory very different from Hume's and is supported by arguments with a quite different flavor. E.g., Arthur Ripstein, Force and Freedom: Kant's Legal and Political Philosophy (2009), at 86106. The normative upshot of Kantian property theory, however, is arguably much closer to Humean property theory than to Lockean theory or resource egalitarian theories. A thorough comparison of Humean property theory to Kantian property theory would require its own article. 
philosophy usually take John Locke as the central figure. ${ }^{5}$ Neo-Lockean property rights are "natural" rather than conventional and relatively invariant across different social contexts. ${ }^{6}$ They reflect pre-institutional moral entitlements justified by desert or first appropriation. The justification of neo-Lockean property entitlements depends on their historical pedigree, but does not (except in extreme cases) depend on the overall distribution of property rights. A neo-Lockean theory of property has several elements. First, there must be rules that license first appropriation. Second, various rules allow property owners to modify or transfer their holdings. These rules should be quite permissive since the ability to trade is an important part of human freedom. Third, there are rules specifying compensation for property that is taken or damaged. Property entitlements are justified insofar as their provenance conforms to these rules of justice. Entitlements are, in this sense, path dependent. They are also nonsystemic in that property that is justly acquired is a full-blooded moral entitlement regardless of the broader distribution of property rights. Finally, property rules are relatively inflexible. Like property entitlements, the rules of just acquisition, contract, and tort do not depend on contextual facts about the broader distribution of property. Instead, they are a matter of "natural right."

Most neo-Lockean theory appeals to moral desert, personal freedom, or a combination of the two in order to justify strong property entitlements. Appropriation by "mixing labor" might justify ownership in virtue of a moral entitlement to the products created through one's own labor. ${ }^{7}$ Alternatively, first appropriation might be justified by people's interest in controlling certain resources exclusively so that they can pursue their personal projects. ${ }^{8}$ Once property has been legitimately acquired, neo-Lockeans support strong property rights and extensive freedom of contract. Again, there are a variety of possible justifications for this stance. Freedom of contract might be thought necessary to allow people to receive the full benefit of their efforts and talents. Alternatively, one might argue that consenting adults should be free to form agreements to do anything that does not directly harm third parties on the grounds that people should

5. E.g., Jeremy Waldron, The Right to Private Property (1988); Nozick, supra note 1.

6. Although it is standard to call views such as Nozick's neo-Lockean, I feel a bit queasy about this terminology. How best to interpret Locke's defense of private property is controversial and it may be that Locke's commitments are rather different than those of representative "neo-Lockeans" such as Nozick. For example, first appropriation might be justified as a Pareto improvement in cases in which it makes the new owner better off and nobody else worse off. Locke encourages this interpretation when he makes it a condition of appropriation that the first appropriator leaves "enough, and as good" for others. John Locke, Two Treatises of Government, Treatise II, ch. V, II 27 (Peter Laslett ed., Cambridge University Press 1988) (1690). This passage raises the suspicion that Lockean natural right actually has a rule consequentialist justification. If so, one might question whether "neo-Lockean" theories are truly Lockean.

7. See Eric R. Claeys, Productive Use in Acquisition, Accession, and Labour Theory, in PHILOSOPHICAL Foundations of Property Law 13-45 (James E. Penner \& Henry E. Smith eds., 2013).

8. E.g., Lomasky, supra note 1; Mack, supra note 1. 
enjoy the maximal freedom from restraint compatible with equal freedom for others. Obviously, these two lines of argument may be mutually supporting to some extent.

The scope of legitimate state action is substantially constrained by neo-Lockean property rights. Neo-Lockeans sometimes embrace an actual (rather than hypothetical) consent standard for political legitimacy. ${ }^{9}$ According to such theories, a property right legitimately acquired in the "state of nature" must be respected whether or not its holder chooses to join a state. The bounds of governmental authority are determined by consent by the governed. On any version of neo-Lockean theory, property owners have broad rights against unwanted incursions by the state unless they choose to alienate their property rights. Such unwanted incursions include regulation of what property owners may do with their property beyond the minimum level of restriction necessary for maximal equal freedom for all property owners as well as taxation that goes beyond what is necessary to support the minimal state. Neo-Lockean theories are minimally (at most) concerned with egalitarian distribution of property. Because people have a natural right to the means necessary to sustain life, Locke held that people have a right to some minimal level of support if they are too poor to feed and clothe themselves. ${ }^{10}$ Neo-Lockeans likewise tend to accept some minimal level of welfare rights. However, beyond this bare minimum, many neo-Lockeans argue that the state is not justified in engaging in any further redistributive projects.

The most popular alternative to neo-Lockeanism is what I will call "resource egalitarianism." ${ }^{11}$ Resource egalitarian theories evaluate property rights in light of egalitarian principles of distributive justice. Resource egalitarians deny that pre-institutional moral entitlements to property such as

9. Notably, Robert Nozick begins Anarchy, State, and Utopia with the question of whether there should be a state at all. Nozick, supra note 1 , at 3 .

10. Locke, supra note 6 , at Treatise I, ch. I, II 42.

11. Jeremy Waldron, whose tripartite division of property theories I am indebted to, categorizes theories of property that I am calling "resource egalitarian" as "neo-Rousseauian." Waldron, The Advantages and Difficulties of the Humean Theory of Property, supra note 3, at 85. I use different terminology for several reasons. First, although Rousseau may have held views somewhat similar to those of contemporary resource egalitarians, the logic of his position is quite different. Rousseau is mainly concerned with material inequality because it is a threat to political equality and good government. The modern conception of distributive justice dates to the late eighteenth century, slightly postdating Rousseau. See Samuel Fleischacker, A Short History of Distributive Justice (2004). Although resource egalitarians typically share Rousseau's concern that material inequality corrupts the political process, their main reason for favoring egalitarian distributive outcomes is typically that they believe that they are required by principles of equal moral status or worth. E.g., "In Part I of this essay we considered the claims of equality of welfare as an interpretation of treating people as equals. In Part 2 we shall consider the competing claims of equality of resources." Dworkin, supra note 2, at 283. Moreover, there are certain theories that arguably count as neo-Rousseauian by virtue of their emphasis on the importance of justifiability to free and equal people that do not favor egalitarian distributive principles. For example, Gerald Gaus explicitly cites Rousseau as the inspiration for his theory of justification but uses this theory to argue for a form of classical liberalism that significantly limits redistributive policies. GAUS, supra note 3, at 24-28. 
Lockean natural rights constrain legitimate state action. Instead, the distribution of property rights should be based on principles governing political institutions that are appropriate for free and equal people. There are many candidates for the principle governing distribution: Rawls's difference principle, equal opportunity for welfare, ${ }^{12}$ an envy-free division of resources, ${ }^{13}$ and so on. Although resource egalitarians are sharply divided on the principles that should determine property rights holdings, they share a common view of the sort of question at issue. Ronald Dworkin and G. A. Cohen are representative resource egalitarians.

Resource egalitarian theories have a number of distinctive characteristics. First, they are typically ideal theories in the sense that they tend to abstract from questions of motivation and stability by assuming some sort of ongoing political community regulated by principles of justice. Some resource egalitarians even abstract from the question of whether people will comply with just principles on the grounds that justice is a matter of what people ought to do rather than a set of policies designed based on predictions about what people actually will do when faced with various possible sets of rules. ${ }^{14}$ Other theorists take stability into account in a fairly restricted way. Rawls allows the parties in the original position to consider the extent to which rules selected in the original position will contribute to social stability. ${ }^{15}$ But since Rawls assumes a society in which people are motivated by suitably chosen principles of justice, it is difficult to know how much this matters. ${ }^{16}$ In any case, there is a strong tendency for resource egalitarians to downplay questions of social stability and moral motivation or abstract away from them entirely.

Second, resource egalitarian theories appeal to a conception of justice based on equal moral status. Brian Barry divides theories of justice into those based on mutual advantage and those based on impartiality. ${ }^{17}$ Theories of justice as mutual advantage conceive of justice as adherence to rules that facilitate the long-run interests of all members of a community by restricting various kinds of negative sum activities. On this understanding, rules of justice are a bit like hypothetical contracts between selfinterested actors. Justice as impartiality conceives of justice as a body of rules that regulate people's conduct with one another on grounds that do not unfairly advantage any party. When all parties begin in a similar position with respect to initial endowments and abilities, considerations of mutual advantage and impartiality will tend to yield similar rules. However, when the parties are differently situated, justice as impartiality tends to rule out certain ways of exploiting superior bargaining power

12. Richard Arneson, Equality and Equal Opportunity for Welfare, 56 PнiL. Stud. 77 (1989).

13. Dworkin, supra note 2, at 283.

14. E.g., G. A. Cohen, Where the Action Is: On the Site of Distributive Justice, 26 Phil. \& Pub. Afr. 3 (1997).

15. John Rawls, A Theory of Justice (1999), at 119.

16. Id. at $7-8$.

17. BARRY, supra note 3 , at 8 . 
that may be unobjectionable under theories of justice as mutual advantage. Barry claims to find elements of both theories in the work of Hume and Rawls. ${ }^{18}$ But on the whole, justice as mutual advantage predominates in Hume and justice as impartiality predominates in Rawls. ${ }^{19}$ Likewise, justice as mutual advantage is characteristic of Humean theories of property whereas justice as impartiality is characteristic of resource egalitarian theories. Ronald Dworkin, for example, is quite explicit in arguing that egalitarian principles of distributive justice follow directly from a deep moral obligation to treat people as equals. ${ }^{20}$ Humean theories of justice, by contrast, are entirely compatible with wholesale skepticism about the moral value of equality ${ }^{21}$ as well as with forms of egalitarianism that respect existing property claims. Instead, they are centrally concerned with ensuring stability by appealing to the interests of all members of the community.

A third feature of resource egalitarian theories is that they take a systemic view of justification. In order to know whether a distributive scheme is fair in the sense of respecting equal status, one must know its effect on all parties. Any particular property entitlement must be evaluated against the background of, at the very least, the entire distribution of property rights and quite possibly all of the benefits and burdens of social cooperation. For Rawlsians, the appropriate unit of analysis is the "basic structure" of society. This includes property entitlements, social insurance, and laws concerning contracts, torts, inheritance, taxation, and employment, among other matters. Systemic theories of justification have obvious appeal insofar as property rules are part of a larger web of rights and duties such that advantages in one instance may be balanced by burdens in another. In complex economies, it is very difficult to make judgments about property entitlements in isolation. The Rawlsian solution is to ask whether the basic structure as a whole is justified. Wages and other entitlements fixed under the rules of a just basic structure are just; those that follow from an unjust basic structure are not. Although this methodology has considerable appeal insofar as it can yield relatively determinate results while attending to the full range of normatively relevant considerations, it has the disadvantage that normative consensus about anything seems to require normative consensus about everything. In contrast to the "top-down" resource egalitarian approach, neo-Lockean and Humean theories take a "bottom-up" approach. Both theories begin with the justification of property rights and then use these to help build a more fully specified political order. This has the advantage of allowing localized assessment of property entitlements without evaluation of all aspects of the basic structure.

21. E.g., Joseph Raz, The Morality of Freedom (1986), at 217-244; Peter Westen, The Empty Idea of Equality, 95 HaRv. L. Rev. 537 (1982). 
A fourth feature of resource egalitarian theories is that they are flexible with respect to the rules that implement distributive principles. Since justice is a matter of generating the right distributive outcomes, it is plausible that different rules of private law will be appropriate in different circumstances. For example, private ownership might be appropriate for resources that are not scarce in nature (e.g., uncleared land in some societies) but inappropriate when such a rule would generate objectionable inequalities (e.g., oil and gas resources in a complex industrial economy). There is a vigorous debate over the wisdom of using private law rather than tax and transfer programs to achieve distributive aims. ${ }^{22}$ For resource egalitarians, however, the question of whether to use rules of contract and tort to achieve egalitarian ends or to rely exclusively on tax and transfer schemes is basically a technical one to be made on grounds of economic efficiency, political feasibility, or ease of administration.

Finally, resource egalitarian theories are ahistorical. Distributive patterns that violate egalitarian principles cannot be justified by virtue of having the right history; distributive patterns that are sanctioned by such principles cannot be undermined because they lack the "right" historical origins. Justice for resource egalitarians is not path dependent. Particular property entitlements may be justified by their history only insofar as this history takes place against a background of a just basic structure.

In some guises, resource egalitarianism does not treat property as an interesting normative category at all and instead takes a purely instrumental view of property rights. In general, the more abstract the egalitarian principles in question, the further downstream property rights appear from philosophically interesting questions about justice. For this reason, it is somewhat unclear whether forms of egalitarianism, such as welfare egalitarianism or the capabilities approach, that favor a highly abstract currency of egalitarian justice should be considered theories of property as opposed to theories with important implications for property. For the purposes of my argument in this article, not much hangs on the exact boundaries of the category.

How to categorize utilitarianism is an interesting question. There is a sense in which analysis of property rights in terms of welfare maximization is a resource egalitarian view that takes the normatively relevant sense of equality to be the equal moral significance of each person's welfare. A variant of Rawls's position that replaces the difference principle with distribution according to welfare maximization would seem to count as a resource egalitarian view at least under a broad definition of the term. Some utilitarians take an instrumentalist, top-down view of property rights similar to that

22. E.g., Louis Kaplow \& Steven Shavell, Fairness Versus Welfare (2006); Christine Jolls, Behavioral Economics Analysis of Redistributive Legal Rules, 51 VAND. L. REv. 1653 (1998); Chris W. Sanchirico, Taxes Versus Legal Rules as Instruments for Equity: A More Equitable View, $29 \mathrm{~J}$. LEGAL STUd. 797 (2000). 
of deontological resource egalitarians but with a different foundational normative principle. Some strains of "law and economics" literature in this instrumentalist vein tend, like many resource egalitarians, not to treat property as a particularly interesting or distinctive category. ${ }^{23}$ Humean property theory is, of course, not inconsistent with utilitarian moral foundations or with a transaction costs analysis of private law. Indeed, parts of Hume's argument could be recast in the language of transactions cost economic analysis. However, it differs from narrowly instrumentalist approaches both in its emphasis on the importance of property rights for political order and in its accent on the ways in which property conventions are partially determined by psychological propensities that may make it difficult to alter them even when doing so is desirable on economic or political grounds.

\section{HUMEAN THEORY}

Humean theories of property rights occupy an intermediate position between neo-Lockean and resource egalitarian views. ${ }^{24}$ Humean theories appeal to the systemic benefits of stable property entitlements as justifying strong, conventional property rights. Humean property rights emerge from conventions between persons who have partially overlapping and partially conflicting interests. ${ }^{25}$ Property conventions serve the public interest generally because everyone benefits from an environment in which possessions are respected, resource conflicts are not resolved by force, and people can engage in commerce, philanthropy, and other activities that are only possible when possessions are secure. Property rights do not depend on legitimate political authority, universal moral norms, or explicit consent. ${ }^{26}$ Convention is both necessary and sufficient. Furthermore, according to Hume, legitimate political authority is also a matter of convention, so even insofar as property rights might be created or modified by a

23. Thomas W. Merrill \& Henry E. Smith, What Happened to Property in Law and Economics?, 111 YALE L.J. 357 (2001). Merrill and Smith's own work is a notable exception to this trend.

24. Just as neo-Lockean theories are inspired by Locke's work but arguably depart from it in certain respects, neo-Humean theories do not perfectly match Hume's actual theory.

25. David Hume, A Treatise of Human Nature (L. A. Selby-Bigge ed., Clarendon Press 1886) (1739-40), at bk. 3, pt. 2, §2, 49. Further citations will be to the Selby-Bigge edition of the Treatise.

26. In the Treatise, Hume treats property as emerging prior to states or formal governments. By the time he wrote his histories, however, Hume conceded that primitive political organization in the form of trial chieftains arose among the Anglo-Saxons and other Germanic tribes before property in land. These chieftains granted land as a sort of pay for military service. This suggests that "primitive" Europeans had social structures based on personal allegiance rather than private property. See Andrew Sabl, Hume's Politics: Coordination and Crisis in the History of England (2012), at 97-100; Annette C. Baier, The Cautious Jealous Virtue: Hume on Justice (2010), at 95-96. This later view seems to be the more realistic one: although all societies must devise ways to manage resources, a network of personal obligations may substitute for impersonal property rights in performing this function. Private property rights have a number of advantages over rule by tribal chieftains or village elders, but are less universal than Hume seemed to believe at the time he wrote the Treatise. 
government, this does not vitiate the conventional roots of property rights. This distinguishes Hume's view both from natural rights theories like John Locke's and from that of his fellow natural rights skeptic, Thomas Hobbes, who argued that property rights require an authoritative lawgiver for their creation and protection. The content of property rules is shaped by the twin requirements of common interest and mutual expectation. Rules that do not tend toward the public interest will not be stable because people will not have conditional preferences to follow them on the condition that others do. And rules that are excessively complex, opaque, or are not psychologically salient will not be adopted because they are unlikely to be the object of mutual expectation. Because property is not, at its core, a matter of formal agreements, laws, or universal moral rules, but instead a complex set of behavioral dispositions, property rights are at once both robust and fragile. They are robust because once a community of people has internalized the relevant dispositions, property conventions can often be maintained without external enforcement. But property rights are fragile because when circumstances undermine expectations about the behavior of others, property conventions may unravel quickly.

Hume's account of property rights explains both how they emerge and why they are socially useful. In the natural course of affairs, people come to gain control over various objects. People are naturally acquisitive and, all else equal, prefer to obtain more possessions. ${ }^{27}$ Before the emergence of property rights, therefore, they are inclined to take what they can when they can. But mere possession in the absence of any socially recognized right to one's possessions is insecure. Moreover, conflict over possessions is costly and dangerous. Rules of justice emerge slowly as people experiment with different patterns of behavior and come to recognize the advantages of coordinating on property rules. ${ }^{28}$ The initial conventions might arise through a sort of trial and error. ${ }^{29}$ Neighbors refrain from taking each other's possessions. At first, this may be indistinguishable from prudent avoidance of direct conflict. Over time, however, the neighbors may develop expectations that each will act nonaggressively. They may begin to rely on each other's continued good behavior, perhaps by leaving their possessions unguarded from time to time. If these expectations are met, the obvious advantages of peaceable behavior may encourage others to emulate it. Over time, respect for others' possessions may evolve from a collection of bilateral conventions between neighbors to a more general

27. E.g., David Hume, Of the Original Contract, in David Hume, Political Essays 196 (Knud Haakonssen ed., 1991).

28. Justice, as Hume uses the term, picks out roughly the domain of normative relations regulated by private law: "the stability of possession, its transference by consent, and the performance of promises." Hume, supra note 25 , at $\$ 6,526$; $\$ 11,567$.

29. One possibility that Hume does not appear to consider, but that seems Humean in spirit, is that humans, like many other animals, are hardwired with a sense of territoriality and that this makes property conventions-hawk-dove strategies—especially salient. 
convention between members of the community as a whole. ${ }^{30}$ This convention ratifies present distributions of goods (whether they came about by means fair or foul) and establishes rules for appropriation of new property. ${ }^{31}$

This willingness to respect others' possessions is conditional: given the advantages of secure possession and the dangers of fighting over resources, I may be willing to refrain from trying to take your possessions, but only if you refrain from taking mine. In the absence of property conventions, there is no sense in sacrificing one's own interests by respecting the possessions of others. Respect for others' possessions and a free-for-all are thus each potentially stable equilibria. Property rights are better for all than a free-for-all, but stable property conventions require both mutual expectation of compliance and the belief that general compliance with the convention is in the long-run interest of all. ${ }^{32}$ When most people respect property rights, the threat of punishment is often enough to keep most of the rest in line. But punishment is impractical when people are constantly violating the rules. Governments, of course, can make threats of punishment much more credible, but no government has the capacity to monitor and punish constant transgressions. Voluntary compliance and coercive enforcement are thus complements since the more people follow the rules, the easier it is to detect and punish violations.

30. This discussion follows Hume in supposing that property conventions initially arise between members of a community. In reality, it is likely that members of some close-knit groups, such as small hunter-gatherer bands or extended family groups, have little difficulty establishing a system of property rights for personal property. For such groups other forms of close cooperation (e.g., hunting and sharing food) probably preexist private property rights. It therefore might be more realistic to apply Hume's analysis to relations between small collectives (extended families, hunter-gatherer bands, small tribes) that may otherwise be inclined to seize land, livestock, and other valuables from each other in the absence of any convention to the contrary. The structure of the explanation is the same whether individuals or extended families are the unit of analysis.

31. Hume is often credited as being an important forerunner of game theoretic analysis of social norms. E.g., Robert Sugden, The Economics of Rights, Cooperation, and Welfare (2004); Ken Binmore, Game Theory and the Social Contract, Volume I: Playing Fair (1994); Herbert Gintis, The Bounds of Reason: Game Theory and the Unification of the Behavioral Sciences (2009). Although Hume influenced David Lewis's classic modern exposition of convention, the property conventions discussed by Hume differ importantly from Lewis's conventions. David K. Lewis, Convention: A Philosophical Study (1969), at 78. In Lewis's examples of pure coordination games-conventions determining who calls back when a telephone conversation is cut off or what side of the road to drive on-the parties are more or less indifferent as to which rule is adopted so long as everyone follows it. Unlike the coordinating conventions that Lewis explores, management of material resources presents an impure coordination problem in which people have interests that are partially overlapping and partially conflicting. Everyone has an interest in avoiding a destructive free-for-all, but each would also prefer that they control more resources at the expense of others.

32. Highly inegalitarian societies are likely to adopt hierarchical social structures that delegate high status property owners the power to enforce property rights against the masses. In such societies, property conventions might effectively operate only within particular estates (i.e., peasants respect each other's use rights but have little intrinsic motivation to respect the property rights of the landlord; the landlords respect each other's landholdings but do not regard peasants as having standing to complain about the incursions of a neighboring landlord). 
Although observance of conventional property rights is very much in the public interest, the initial adoption of rules of justice is motivated by selfinterest, not public spiritedness. ${ }^{33}$ Because they are initially motivated by considerations of self-interest, property conventions may arise spontaneously even in communities of largely self-regarding actors. As tentative expectations crystallize into social norms, people become inclined to count transgressions as marks of bad character. They come to sympathize with the victims of these transgressions and to condemn acts of injustice without consideration of their own personal interest. What were once considered matters of prudence become questions of morals. New forms of motivation are possible when property rules are moralized. As people gain experience with the favorable social consequences of just acts, they associate justice with peace, prosperity, and harmonious social relations. Once this connection is established, approbation of just acts is motivated by "sympathy with the public interest."

Hume's theory of justice is a form of indirect consequentialism: justice consists in adherence to conventional rules that promote the public interest. In order to settle distributive questions authoritatively, property rules must generally be followed even in cases where they require substantively undesirable outcomes. The conventional nature of property implies that there is a trade-off between optimality and stability. Justice sometimes requires that property be given to the rich and prodigal when it would be of greater benefit to the poor and thrifty because stability of possession cannot be achieved except by respecting rules that are generally applicable. ${ }^{35}$ Property rules thus function as a kind of a second best solution to distributive questions when the best solution would require a sort of situationspecific judgment that would make property entitlements uncertain and invite partiality in application. In exceptional cases, rules of justice may be disregarded on the grounds of public necessity. For example, during a famine the public may open granaries and distribute grain without consent of their owners. ${ }^{36}$ Hume's position is not that justice permits such acts, but rather that in cases of extreme urgency, the principles of justice are either suspended or supplanted by rules of equity. ${ }^{37}$

The overriding advantages of a system of stable entitlements mean that there is a range of possible rules that could be adopted as property conventions. Being in a place where others follow a certain rule can give one sufficient reason to follow it even if some other rule could play the same role in

33. Hume, supra note 25 , at $\$ 6,529$.

34. Id. at $\$ 2,499-500$.

35. Id. at 497.

36. David Hume, Enquiries Concerning the Humean Understanding and Concerning the Principles of Morals (L. A. Selby-Bigge ed., Clarendon Press, 1902) (1751), at §3, pt. 1, 186.

37. As Samuel Fleischacker points out, this position is consistent with traditional natural law doctrine as found in Aquinas and Grotius and so is not a Humean innovation. Fleischacker, supra note 11, at 31-34. 
stabilizing expectations (and even if the other rule might be more desirable). Morally arbitrary conventions can serve the morally vital purpose of preventing wasteful conflict over resources. Although certain property conventions might arise "naturally," in the sense of spontaneously, because of their utility in solving coordination problems, there is no unique "natural" set of property rules that all spontaneously arising conventions must converge on. Considerations of stability count strongly in favor of choosing rules that are simple, psychologically salient, or grounded in existing custom even if some different rule, if followed regularly, might bring about slightly better results. ${ }^{38}$ For example, Hume suggests that the doctrine of accession is grounded in associative psychology. It is intuitive to associate an apple with the apple tree from which it fell and a calf with its mother. This psychological propensity leads people to coordinate on the rule that the owner of an apple tree is the owner of tree's apples and the rule that the owner of a cow is the owner of her calf. ${ }^{39}$ Psychological salience also helps to explain the enormous significance of possession for property and property law. "Everyone gets to keep what they possess" is a simple and salient rule for restricting wasteful competition over resources that is often justifiable in light of the great advantages of stable property entitlements. That the particular contours of property rules may also depend on historical accident seems a clear implication of Hume's approach, although Hume does not emphasize the significance of path dependence in the Treatise.

Hume's moral psychology steered a middle course between predecessors such as Mandeville and Hobbes on the one hand who saw people as motivated largely by self-interest and Shaftesberry and Hutcheson on the other who believed that natural benevolence plays a more important role. ${ }^{40}$ Hume argued that people are characterized by genuine but limited concern for the well-being of others. ${ }^{41}$ Though the welfare of others can be intrinsically motivating, our sympathy for those who are not close associates is sharply limited and tends to decline with social and physical distance. ${ }^{42}$ Justice is necessary for human society in part because people cannot be sufficiently motivated by the welfare of strangers. ${ }^{43}$ Even when people act out of altruistic impulses, their preference for friends and relatives leads them

38. Hume seems to have anticipated Thomas Schelling and David Lewis by two centuries in his emphasis on the importance of psychological salience. See Thomas C. Schelling, The STRATEgy of Conflict (1960); Lewis, supra note 31.

39. Hume, supra note 25 , at $§ 3$. More provocatively, Hume suggests that the same analysis applies to labor as a source of ownership. Labor on an unowned object often gives rise to ownership not because of one's natural right to the value of one's labor but because the salience of labor makes it a good candidate for a convention of first appropriation.

40. Michael L. Frazer, The Enlightenment of Sympathy: Justice and the Moral Sentiments in the Eighteenth Century and Today (2010), at 66; Michael Gill, Hume's Progressive View of Human Nature, 26 Hume STud. 87, 87-88 (2000).

41. Hume, supra note 25 , at $\$ 2,487$.

42. Id.

43. Id. at 487-489. 
into conflict just as self-interest does. Altruism combined with partiality toward one's friends and relations can be even more socially disruptive than unbridled pursuit of narrow self-interest since it facilitates cooperation among members of a family, clan, or tribe in order to aggress against outsiders. Since people have limited sympathy for those who are not close friends or family, social institutions must therefore appeal, at least to some extent, to the self-interest of their participants in order to provide a basis for stable cooperation. People are sensitive to the division of gains from cooperation and likely to resist arrangements in which these accrue almost entirely to others. Hume's theory supposes that in many circumstances people are conditional cooperators whose willingness to follow conventional rules of justice depends on expectations about others' willingness to follow them. ${ }^{44}$ Because property conventions rely on voluntary compliance, they are fragile and can be destabilized if people's expectations about each other's behavior shift quickly or if compliance with property conventions becomes disadvantageous for a significant fraction of the population.

The psychology of conditional cooperation might go some way to explaining how what are initially mere behavioral regularities become moralized. When property norms first emerge, they first appear as tentative expectations and then, as respect for others' possessions becomes more widespread, as a descriptive norm. At this stage, enlightened self-interest may be sufficient to explain compliance. Once a social norm of defending one's own possessions and respecting those of others is in place, a sense of reciprocity may generate feelings of resentment against those who do not reciprocate respect for others' property. When people develop stable expectations concerning others' behavior, respect for property rights becomes the new baseline for fair play and is generalized to apply to all members of a social group. ${ }^{45}$ Violations of property rules are judged to be morally unacceptable because they involve taking advantage of the benefits of property conventions while declining to share the burdens. This sort of blatant free riding is apt to draw moral disapproval from conditional

44. This supposition finds support in contemporary social science. Christina Bicchieri writes, "There is plenty of evidence that most people are conditional cooperators. They cooperate when they expect others to cooperate and defect otherwise. In other words, most people are neither pure altruists nor selfish brutes." Christina Bicchieri, The Grammar of Society (2006), at 140-141.

45. This account has some similarities to psychologist Michael Tomasello's recent suggestion that human morality developed in three stages. See Michael Tomasello, A Natural History of Human Morality (2016). At the first stage, people developed a sense of joint intentionality deployed in cooperative activities. Second, people began to hold their cooperative partners responsible for carrying out their role in cooperative schemes and to make moral demands of cooperative partners. At the final stage, norms that emerge from these cooperative relationships were generalized to the entire social group so that all members of the group were expected to follow the rules and each member of the group had standing to hold others accountable. 
cooperators even if property norms were not antecedently strongly moralized.

The question of what motivates compliance with established property conventions is more complex. Humean property theory is consistent with several distinct accounts of moral motivation, each of which has at least some affinities with Hume's argument in the Treatise. One possibility is that compliance with property conventions is motivated by individual longrun self-interest. Ken Binmore is a leading proponent of this sort of neo-Humean political theory and credits Hume with explaining cooperation in terms of reciprocal altruism (an insight rediscovered by game theorists and biologists in the twentieth century). ${ }^{46}$ Binmore argues that social contracts - the set of norms governing the social behavior of members of a society ${ }^{47}$ - specify rules of action that form Nash equilibria. ${ }^{48}$ Rules of jus- $^{-}$ tice tend to evolve toward Pareto efficiency (at least insofar as it is consistent with stability) because rules that are not Pareto efficient forgo potential gains that could be divided in a mutually advantageous way. ${ }^{49}$ Changing conditions may disrupt a social contract that is at equilibrium by changing the payoffs for various strategies. When this occurs, social norms must be adjusted to reach a new Nash equilibrium. Property conventions, on this account, consist in a complex set of norms specifying property rights and punishments for breaking them that give all self-interested people sufficient incentive to follow the rules if they expect others to follow them as well.

Binmore's hardline rational choice moral psychology requires that much seemingly altruistic behavior be explained away. In contrast to some rational choice theorists, however, Binmore is not skeptical about the importance of social norms and moral emotions in explaining behavior. ${ }^{50}$ Binmore believes that some actions that might seem to violate the predictions of rational choice models, such as turning down nonzero offers in the ultimatum game, reflect an emotional response to the violation of social norms. People rely on norms, strategies, and heuristics that they have picked up elsewhere when confronted with unfamiliar circumstances. But given sufficient time and sufficient incentives, they will tend to "unlearn" moral norms that do not further their aims in life. Binmore's theory is therefore compatible with a psychology that allows both moral emotions and moral rules to

46. Ken Binmore, Game Theory and the Social Contract, Volume II: Just Playing (1998), at 265; Hume, supra note 25, at $\$ 3,521$.

47. It is important to note that Binmore's social contract is emphatically not a set of basic laws regarding political institutions, but rather is based on fundamental conventions that are prior to any formal state institution. The social contract specifies, among other things, rules for complying with or ignoring governmental authorities as well as for punishing those who do not play by the rules. Governments and formal laws are therefore the products of social contracts that state that people should cooperate with them, at least in some circumstances.

48. Binmore, supra note 31 , at 41 .

49. Societies with massively inefficient social contracts also are at risk of being conquered or having their members recruited away by societies that are more efficient.

50. Ken Binmore, Natural Justice (2005), at 83-84. 
be proximately motivating. Where it differs from other versions of neo-Humean moral psychology is on the question of whether the public interest or intrinsic concern with interests of others ultimately motivates compliance with moral norms. ${ }^{51}$

A second possible source of Humean moral motivation is sympathy with the public interest. In the Treatise, Hume argues that "self-interest is the original motive to the establishment of justice; but a sympathy with public interest is the source of the moral approbation, which attends that virtue."52 Hume's observation relates to the source of moral approbation of just acts, but it is consistent with the notion that people might also be motivated to act out of sympathy with the public interest. On one interpretation of Hume's theory, although people are not capable in their "natural" condition of being intrinsically motivated by justice, their dispositions can change as a result of the "progress of sentiments" so that in a civilized condition they may be motivated by considerations of justice quite apart from self-interest. $^{53}$

The crux of this second theory of moral motivation is that compliance with the rules of justice can been seen as a contribution to a public good. A person may follow widely accepted property rules out of a sense of common interest in upholding these rules even in cases in which it is individually advantageous to violate them. On this account, people are conditional cooperators who usually follow property conventions regardless of their expected gains or losses so long as they (a) believe that others will mostly obey the rules, (b) believe that general observance of the rules is in the public interest, and (c) expect to share in the benefits that flow from general observance of these rules. This is not to say that conditional cooperators are insensitive to the costs and benefits of just acts: people will usually act justly when this requires only small personal sacrifices and are more likely to act unjustly when they can secure some great gain for themselves. Sugden, while acknowledging that Hume appears to argue to the contrary, expresses skepticism that sympathy with the public interest can be sufficiently motivating. ${ }^{54}$ There is something somewhat incongruous here with Hume's skepticism about the motivating power of sympathy with those distant from ourselves: if rules of justice are apt for situations in which natural sympathy is insufficient to assure good behavior, it seems peculiar to argue that sympathy with an abstract collective largely made up of such people will do the trick. Perhaps "self-love" combined with identification of oneself as a member of a collective that shares certain interests can go some way

51. Binmore's position, like Hume's, is compatible with intrinsic concern for the welfare of others motivating a variety of individual altruistic acts. What both deny is that this is sufficient to explain respect for property rights and other rules of justice.

52. Hume, supra note 25 , at $\$ 2,499-500$.

53. Gill, supra note 40, at 98-100. Jacqueline Taylor, Justice and the Foundations of Social Morality in Hume's Treatise, 24 Hume STud. 5, 5-30 (1998).

54. Sugden, supra note 31 , at 175-176. 
to resolving this apparent contradiction. But in cases concerning large collectives-and rules of justice mostly concern such situations-it seems a stretch to argue that people usually weigh their interest in upholding the rules of justice qua member of the public as outweighing the potential benefits of being a rule breaker.

One potential response to this difficulty is to identify sympathy with the public interest not as directly motivating just acts but instead as providing a motive to treat the rules of justice as authoritative. This is what Stephen Darwall argues is the most attractive interpretation of Hume's position. ${ }^{55}$ Darwall's interpretation of Hume's moral psychology of artificial virtue might go some way to explaining how a sense of common interest can be motivating. Conforming one's actions to the rules of justice is a contribution to a public good, namely the conventions that make harmonious life in complex societies possible. ${ }^{56}$ Like many public goods, this is a collective project. Since the point of conventions is to coordinate one's behavior with others, there is no sense in following rules that one does not expect others to follow. But if others are disposed to follow the rules, then to treat the rules of justice as binding on oneself is to do one's part in a common project. Once a person has decided to treat the rules of justice as authoritative, she does not typically weigh sympathy with the public interest against her particular ends. Instead, justice preempts other considerations.

A third possible motivation for compliance with rules of justice is strong reciprocity. Strong reciprocity is "a predisposition to cooperate with others, and to punish those who violate the norms of cooperation, at personal cost, even when it is implausible to expect that these costs will be repaid." ${ }^{, 7}$ Strong reciprocity is distinct from generic altruism in that it involves intrinsic motivation to help those who help oneself rather than some more general motivation to help others. It is distinct from enlightened self-interest in that it motivates genuinely self-sacrificing behavior in cases where an agent knows that she will receive no future benefit. For example, one might care for a dying friend who has been helpful in the past even when there is no prospect that this final act of kindness will be reciprocated. There is a plausible functional explanation for strong altruism as a psychological trait. In order to secure favors from others, it is best to appear to be the sort of person who will reciprocate favors in the future. But sometimes returning a favor is costly and sometimes there is no prospect for any future advantage. People will want to help others who are disposed to return a favor even

55. Stephen Darwall, Motive and Obligation in Hume's Ethics, 27 Noûs 415 (1993).

56. Justice is not quite a pure public good in the technical sense of a good that is nonrival and nonexcludable. Conventions of property, promise, and contract are nonrival since one person's benefits from participation in the conventional practice do not threaten another person's ability to benefit. To the contrary, one person's participation tends to facilitate the participation of others by enlarging the scope of the conventional practice. However, conventional rules of justice may be partially excludable since one might deny certain people the benefits of being a property owner or a promise, although they might still indirectly benefit from the existence of property rights for others.

57. Herbert Gintis, Behavioral Ethics Meets Natural Justice, 5 Pol., PHiL. \& Econ. 5,17 (2006). 
when they will get nothing further out of the deal. Given that people are always on the lookout to see who can be trusted in cooperative ventures and who cannot, it would be useful to be able to signal that one will return favors. And the surest way to do this is to actually be such a person. Proponents of strong reciprocity sometimes suggest that this form of motivation may be hardwired into human psychology. ${ }^{58}$ But regardless of whether strong reciprocity has biological underpinnings, there is abundant anthropological evidence that reciprocity norms are ubiquitous.

Strong reciprocity differs from "sympathy with the public interest" in that it postulates that people have a very general intrinsic motivation to reciprocate favors that goes beyond contributions to common projects. Strong reciprocity can motivate compliance with property rules even among people who are relatively agnostic about the utility of these rules. People who are intrinsically motivated to reciprocate favors may respect the property rights of others not because they judge that this serves an important public purpose but because they think that they owe this to those who respect their own property. Given the complexity of determining which property rules serve the public interest (and the disinclination of many people to engage in such abstract speculation), strong reciprocity could lead to more stable compliance than either enlightened self-interest or sympathy with the public interest. For example, strong reciprocity can provide a motive to respect property rights even for those ideologically opposed to private property.

The three candidate theories of moral motivation have somewhat different implications for the content of Humean property theory. The enlightened self-interest theory and the strong reciprocity theory lend themselves to development of Humean theory in a contractarian direction since they posit that people are more sensitive to individual outcomes than social outcomes. As a grounding for Humean political theory, strong reciprocity is promising in providing an empirically plausible account of large-scale cooperation without presupposing the sort of general public benevolence that Hume found unrealistic. The "sympathy with the public interest" interpretation is more congenial to rule utilitarianism since it builds in concern with social outcomes. But although it is arguably more congruent with Hume's broader moral theory, as a descriptive matter it fits somewhat uneasily with Hume's skepticism about the efficacy of public benevolence.

\section{THE ADVANTAGES OF HUMEAN PROPERTY THEORY}

According to Humean theory, the advantages of property rights as a basis for social cooperation may justify property entitlements that are entirely

58. Whether this functional explanation is also a plausible evolutionary explanation is more complicated. Under some circumstances, (it is very controversial just how wide such circumstances are), natural selection might select for those who are intrinsically motivated to return favors to fellow cooperators regardless of their personal payoff. 
morally arbitrary outside of the context of the particular social conventions that support them. This is an important point of contrast with neo-Lockean theories and other natural rights views. Lockean rules of first appropriation might be the object of Humean property conventions. But it is not necessarily an injustice if they are not. For a Humean, even if the initial distribution of possessions is determined by a mix of luck, thuggery, and fraud, the emergence of property conventions converts mere possession into fullblooded property. Indeed, the evolution from bandits to barons should be commended as social progress.

By contrast, the source of property entitlements presents a series of awkward questions for neo-Lockeans. If one looks closely, the historical provenance of many property claims is rather dubious. Examine the chain of title for any given plot of land closely enough and it is likely to begin with some disreputable act of thievery or fraud. The original occupier of a piece of land is, more often than not, someone who took it by force. And when this is not the case, the original title often reflects a grant from a government that dispossessed the prior owner in some morally dubious manner. Lockeans are thus faced with a quandary. If they take a hard line against dubious property claims, Lockean theory will tend to undermine the claims of present possessors in ways that seem worrisome. At first blush, a theory such as Nozick's seems to call a huge range of property claims into question. Intellectual property of various kinds may be relatively unproblematic because patents, copyrights, and trademarks usually are of recent vintage. But almost any kind of land claims and some chattels would be under a cloud. Commerce does not help matters here. The usual rule is that a seller who does not possess good title cannot transmit good title to a buyer-otherwise thieves could easily profit from their ill deeds by selling property to clear title. Lockeans might argue that title could be "cleansed" by improvements that require significant labor on the part of the new owner. This seems plausible in some cases. Homesteaders in the West might be thought to acquire moral rights to their farms through labor even if the government's claim to have the right to grant the land in the first place was questionable. This sort of theory works well when, as in nineteenth-century America, land is very plentiful relative to labor. But in other cases, it seems more questionable. When natural resources are scarce enough to have economic value, income reflects returns to both capital and labor. Returns to capital tend to average around 5 percent in the modern era. ${ }^{59}$ Even without any special investment skill, ill-gotten gains can easily grow over time rather than diminish. Natural resources sometimes appreciate in value for reasons that have nothing to do with labor or investment. For example, land in Manhattan is fantastically valuable with or without "improvements." Finally, the labor theory of ownership creates numerous

59. Thomas Piketty, Capital in the Twenty-First Century (Arthur Goldhammer trans., 2014), at $206-209$. 
line-drawing problems. Can an absentee landlord gain a moral right to property through improvements made by their tenants? Does construction of residential buildings count as an improvement that gives rise to a valid claim to the land underneath it? Does ordinary upkeep of a house require enough labor for Lockean principles to apply? Once we set aside the Lockean fiction that natural resources have little economic value, many cases raise hard questions. The uncertainty of these questions suggests that Lockean labor theory of value is poorly suited to underwrite property rights in a complex economy.

One possible solution to the uncertainty of property entitlements is to adopt a strong principle of adverse possession. Adverse possession is the legal doctrine that allows an occupier of land to gain legal title after some period of continuous and conspicuous occupation despite lacking any preexisting right to the land. Adverse possession rules, however, do not follow neo-Lockean logic. They are not much concerned with how much work the adverse possessor puts into improving the land but rather with whether possession is "open and notorious" (i.e., whether the adverse possessor acts in a way that gives notice to others). In many jurisdictions, the adverse possessor need not even be acting in good faith! ${ }^{60}$ The apparent policy motive is to promote clear title, not to reward the industrious. Of course, one could make adverse possession doctrine more Lockean by requiring significant investment or improvement and, perhaps, good faith. But there are good reasons to be cautious about such an approach. "Improvement" is a much more nebulous standard than possession. To the extent that improvement is read narrowly to include only actions that greatly increase a plot's market value, many titles will be unclear. Moreover, possessors might have undue incentive to "improve" land merely to establish title even at the cost of long-term environmental damage. The environmental effects of encouraging slash-and-burn agriculture on the property of others would be deleterious to say the least. To the extent that improvement is read broadly so that minimal investments are sufficient for title, adverse possession will still reward the "undeserving." In this case, the Humean amendment threatens to swallow the Lockean system as claims of present possession supersede claims of natural right.

Although Humean theories and Lockean theories have deeply opposing stances on the grounds of property entitlements, Humean theory can assimilate many aspects of Lockean theory. For example, considerations of moral desert are compatible with Humean theory so long as they supplement fundamental property conventions rather than replace them. The problem with Lockean claims, according to Humeans, is that property rights ultimately rest on fundamental conventions of respect for others' possessions. And these cannot be stable if they require widespread moral agreement about who deserves what. Once such fundamental conventions are in

60. Henry Smith \& Thomas Merrill, Property: Principles and Policies (2007), at 207. 
place, considerations of moral desert may be helpful in filling in the more detailed rules about how to acquire unowned goods. Widely shared moral intuitions about certain relations between people and objects might be good candidates for certain such conventions. But to think that nonconventional moral rules can replace the fundamental convention is to put the cart before the horse.

Some purportedly Lockean arguments might be improved by being recast as Humean. For example, although Richard Epstein presents his approach as neo-Lockean, ${ }^{61}$ his political theory is more attractive if Epstein is read as a conservative Humean rather than as a neo-Lockean. Epstein's approach to property theory is Humean in its emphasis on the importance of possession as the source of property entitlements. ${ }^{62}$ Epstein casts doubt on labor as a source of moral entitlement to property and rejects Locke's claim that property is initially owned by all humanity in common. ${ }^{63}$ His focus on possession as the source of title and his defense of adverse possession emphasizes the importance of clear title rather than desert in determining the rules for acquisition of property. ${ }^{64}$ This is more Humean than Lockean in flavor both in terms of its underlying consequentialist logic and in its focus on physical possession rather than moral entitlement based on labor.

Epstein's analysis of takings provides a way to reconcile robust property rights with public regulation that restricts the rights of property owners without consent. Neo-Lockean theory has trouble with situations that require constraining property owners rather than empowering them. Problem spots include eminent domain, activities that pose risks to one's neighbors, and environmental regulations. Epstein's analysis of takings provides a way to justify force exchanges without vitiating the content of property rights. Epstein argues that restrictions of property rights are justified if they serve a public purpose and provide the right holder with sufficient compensation for the loss of her property rights. This might involve cash payments, but could also include in-kind benefits from the imposition of regulation. ${ }^{65}$ For example, a new zoning code might reduce a homeowner's freedom of choice with respect to alternations of her own home, but nevertheless increase the value of her house by restricting the rights of her neighbors. Because the zoning code cannot be effective without being binding on the entire neighborhood, imposition without the consent of each individual $3-6$.

61. See Richard Epstein, Takings: Private Property and the Power of Eminent Domain (1985), at

62. Richard A. Epstein, Possession as the Root of Title, 13 GA. L. REv. 1221 (1978-1979) [hereinafter Epstein, Possession as the Root of Title]; Richard A. Epstein, Past and Present: The Temporal Dimension in the Law of Property, 64 WASH. U. L.Q. 667 (1986) [hereinafter Epstein, Past and Present: The Temporal Dimension in the Law of Property].

63. Epstein, Possession as the Root of Title, supra note 62, at 1227-1230.

64. Epstein, Possession as the Root of Title, supra note 62, at 1238-1243; Epstein, Past and Present: The Temporal Dimension in the Law of Property, supra note 62, at 674-680.

65. EPSTEIN, supra note 61, at 196-202. 
homeowner may be justified. Epstein's approach thus replaces consent with an appeal to public benefit and fair compensation for individuals.

Epstein's arguments for neo-Lockean limitations on government are less successful. In the first chapter of Takings, Epstein argues that fair cooperation requires that all people share in the gains from government in proportion to their holdings of Lockean rights in the state of nature. ${ }^{66}$ Even if one grants the initial condition, this argument faces a number of serious difficulties. First, the sort of cooperation made possible by government will often change the value of Lockean state of nature holdings immensely: the relative value of skill in bashing one's neighbors' heads declines immensely and the returns to skill in managing large organizations may increase hugely. Making gains proportional to initial shares would require extensive and burdensome government intervention. Second, there is little reason to think that a proportionality rule would emerge from a bargain between self-interested parties. Third, there is no reason to think that citizens make contributions to supporting political order in proportion to the value of their property rights in the state of nature. Although Epstein's neo-Lockean distributional claims fail, his takings analysis, which is more Humean in spirit, is sufficient to justify the coercive imposition of government that makes the public as a whole better off and leaves no individual worse off.

Humean theory is a straightforward competitor to Lockean theory. Humean theory aims to displace Lockean theory by showing that Lockean property rights either can be explained in Humean terms as the object of conventions or are not justified because they appeal to implausible principles or yield undesirable results. The relationship between Humean property theory and resource egalitarianism is more complex. Resource egalitarians usually agree with Humeans that property entitlements are based on conventional rules rather than on "natural rights" and so in this respect the two approaches are opposed to neo-Lockeanism. Where the Humean and resource egalitarian theories come apart is on the conditions necessary for property rights to be justified. According to Humean theory, existing property entitlements have normative significance that is independent from their contribution to some larger distributive scheme. Property conventions are valuable because they address a crucial problem for cooperative social life. The regulation of access to scarce resources presents a coordination problem. A system of property rights solves this coordination problem by assigning rights to regulate access. In order for property rules to serve this function, certain questions must be considered settled so that people do not have to solve their coordination problem from scratch each time a new question arises. Just as being an effective agent might require treating one's intentions as having at least provisionally settled certain questions, treating certain questions concerning access to resources as settled by

66. Id. at 3-6. 
property conventions might be necessary for complex forms of social cooperation. ${ }^{67}$ Because the persistence of conventions requires continued compliance by most people most of the time, conventional property rights are to some extent fragile. Any property convention that manages to solve the coordination problem arising from resource scarcity ought to receive at least some weight in normative deliberation. Existing property conventions therefore have moral significance even when they are not based on Lockean natural rights and do not meet resource egalitarian standards for public justification in light of some conception of equality. From this perspective, the problem with both neo-Lockean and resource egalitarian approaches is that they invite moral claims that threaten to unsettle property conventions. ${ }^{68}$

An important advantage of Humean property rights is that they can enable cooperation between people who do not agree on basic questions of distributive justice. By contrast, justification of property entitlements under resource egalitarian theories is rather fragile. Agreement on property rights, tax rules, and so forth requires agreement on the underlying principles of justice. But these principles are extremely controversial: there are almost as many resource egalitarian theories as there are resource egalitarians. And of course, some people reject all resource egalitarian theories. Although there may be fairly broad consensus among resource egalitarians that, for example, there should be some form of progressive taxation, there are stark differences about the extent to which differences in wealth holdings are permissible. John Rawls's response to this problem in Political Liberalism is to argue that principles of justice can be the object of an overlapping consensus between people who endorse various "reasonable comprehensive doctrines." ${ }^{69}$ In other words, all citizens can endorse common principles of justice even though they each may do so for slightly different reasons. Justification of basic civil liberties seems a better fit for this methodology. Matters of distributive justice are more divisive-even stable Western democracies with wide public consensus on civil liberties feature rather significant disagreements about, e.g., progressivity in taxation, social insurance, welfare, economic regulation, and property rights. This is not surprising: although the interest of most supporters of mainstream parties in "advanced democracies" is relatively symmetric when it comes to basic civil liberties, material interests concerning distributive justice diverge quite plainly. And these differences often cut across other lines. For example, people who consider their Catholic faith to be central to their political views embrace an extremely wide range of views on economic policy.

67. This analogy draws on Michael Bratman's work on intentions. See Michafl Bratman, Intention, Plans, and Practical Reason (1987).

68. My claim here has similarities to Scott Shapiro's recent argument that Dworkinian jurisprudential methodology threatens to destabilize the legal system by allowing the substantive moral views of the interpreters of legal texts to upset established legal conventions. See ScotT Shapiro, Legality (2011).

69. John Rawls, Political Liberalism (1996), at 140-154. 
By contrast, Humean property theory suggests that private property rights are useful in part because of the role they can play in facilitating cooperation between those who disagree about fundamental moral principles. In order to serve this function, existing property conventions, whether or not they are congruous with natural property rights, may require a sort of deference to existing rules that fits uneasily with the resource egalitarian approach. Humean property conventions may not reflect anyone's ideal preferences. But people with very different moral views might agree that Humean property conventions serve both the interests of the public as a whole and the private interests of individuals in comparison with a free-for-all. Simply because property convention $\mathrm{Z}$ would bring about a more equitable distribution of property than the existing convention $\mathrm{A}$ does not mean that one is justified in disregarding $\mathrm{A}$ in favor of $\mathrm{Z}$.

Resource egalitarians might agree that people should not feel free simply to disregard property laws that they find nonoptimal. Instead, the state should respond to considerations of distributive justice by moving to convention $\mathrm{Z}$ from convention $\mathrm{A}$, perhaps with some transition policy. Humeans, by contrast, regard existing property conventions as analytically prior to the state and as constraining government policy to some extent. Property rights are meant, in part, to authoritatively settle distributive questions in order to prevent wasteful conflict over resources. If, instead of property entitlements being settled by property law, political authorities are allowed to determine property entitlements without any real constraints, this simply displaces the danger of self-defeating conflict over resources into the public sphere. And this raises its own set of challenges. According to Hume, political authority is at root conventional. ${ }^{70}$ People obey governments (to the extent that they do) in part because they expect others to do so. Effective government, like a system of property rights, is a public good that requires compliance from a large part of the population in order to be realized. A government that does not command its subject allegiance cannot perform its essential functions and therefore may be ignored. By contrast, even a morally compromised government is worth listening to if the alternative is anarchy. Under ordinary conditions, conventions of obedience to the state and conventions of property are distinct but mutually reinforcing. The state reinforces property conventions by specifying the precise contours of property entitlements and by punishing violations of property rights. Property entitlements reinforce dispositions of obedience by giving citizens a stake in preserving the existing legal order. Stable property conventions and stable political conventions are therefore likely to go together. And the converse is true for political and property instability. Setting aside existing property conventions puts greater stress on conventions of political authority in maintaining public order. A Hobbesian state that can redefine property according to whatever theory

70. See Hume, supra note 25 , at $\$ 7$. 
holds sway with the government raises the stakes for political control greatly. To the extent that citizens agree on principles of distributive justice, this may not be a problem. But under the more realistic assumptions that questions of distributive justice are deeply controversial, greatly altering property conventions may undermine dispositions to obey political authorities when out of power and to refrain from taking a maximalist position when in power. The Hobbesian state can be used by reactionaries as well as egalitarians. Once conventional entitlements are set aside, it may be difficult to identify compromise positions that can satisfy competing factions as a neutral baseline. Insofar as opposing factions treat existing entitlements with a fair degree of deference when they are in power, reasonable critics of the status quo have reason to do so as well. When they cease to do so, all bets are off.

The Humean approach requires that existing conventions and existing entitlements be treated as the normative baseline when one is contemplating reforms. Unless this is done, resource egalitarian and neo-Lockean ideologies will tend to undermine the conventional basis of political authority. ${ }^{71}$ As will be discussed below, conservative and liberal Humeans might disagree about the precise boundaries of permissible changes but both camps agree that a significant degree of deference to existing conventions is necessary. Change may come in one of two forms: changes to property conventions or changes to property entitlements. Prospective changes to property conventions are relatively unproblematic if circumstances have changed such that the new convention will bring widespread benefits. To the extent that there are losers from the change, these might be compensated using some of the surplus created by moving to the new rules (and to the extent that identifiable losers cannot be compensated, this casts doubt on whether the change is really in the public interest). Epstein's takings analysis shows one example of how this might work. However, Hume's analysis of property conventions suggests some limits to the extent to which conventions can be altered. First, many conventional rules of property acquisition are grounded in features of human psychology and so might not be especially malleable. Second, because property conventions require voluntary compliance from most people most of the time, changes that create both winners and losers may end up without enough acceptance to be self-reinforcing. The ability to shift property rules in response to new circumstances is an advantage of Humean theory over neo-Lockean theory. But this power must be used with care: not every adoption of a new rule that might be endorsed by utilitarian or egalitarian distributive principles will be justified in a Humean framework.

71. As will be argued below, extremely inegalitarian property distributions also might have this tendency if the result is that many citizens do not believe that they benefit very much from public order. So the point may cut against neo-Lockean views as well. 
Changes to existing property entitlements are even more problematic. A considerable degree of redistribution can be effected through prospective changes in legal rules, such as more progressive tax rates or labor market regulation, that do not transgress existing entitlements. More aggressive redistribution in the form of outright expropriation is more likely to undermine the conventional foundations of political order. Much depends on context. A polity with well-entrenched conventions of deference to political authority may be able to pursue a more aggressively redistributive policy without undermining political order. However, political orders in which there are public recognized limits (which might be matters of law, but are just as likely to be informal norms or shared understandings) on property redistribution are likely to have an easier time securing compliance with governmental directives since citizens will have less cause to worry that giving an inch will result in the state taking a yard. Redistributive measures in such polities are also less likely to degenerate into transfers to supporters of a politically dominant faction. As Daron Acemoglu and James Robinson have argued, much of recent Latin American history has been characterized by cycles of populist redistributive regimes and authoritarian right-wing regimes in which rival political factions have waged a protracted, destructive battle for political and economic supremacy. ${ }^{72}$ Post-World War II Western Europe and North America, on the other hand, created democratic institutions that ensured that the benefits of economic growth would be shared with workers while giving property owners greater long-term security. This created a virtuous cycle of stability and shared prosperity. The larger point here is that respect for the claims of existing property holders may be crucial for stable cooperation in the face of normative disagreement. Even when these claims do not meet resource egalitarian standards, the long-run results of compromises that protect existing property holders while providing for greater redistribution might turn out better by egalitarian standards. Moreover, analyzing transaction costs by calculating the efficiency losses from expropriation is not sufficient to account for the relationship between political order and respect for property rights.

Resource egalitarians might object that the practical risks and potential unfairness of frustrating expectations under existing property conventions might give egalitarians pragmatic reasons to move more slowly in adopting their preferred property conventions, but would not confer moral status on the existing claims. ${ }^{73}$ This objection is amenable to a strong or a weak interpretation. On a strong interpretation, the pragmatic considerations differ from egalitarian moral considerations in that they are merely prudential considerations that do not give rise to justified moral complaints if they are ignored. In other words, those who lose their entitlements under the

72. See Daron Acemoglu \& James A. Robinson, The Economic Origins of Dictatorship and DEMOCRACY (2005).

73. I am grateful to an anonymous reviewer for this point. 
old conventions have no grounds for moral objection if egalitarians act imprudently in moving too quickly to new conventions. If the Humean approach is correct, there are two independent sources of moral complaint. Stable property conventions are a public good, analogous to the rule of law. If imprudent egalitarians destabilize property conventions, they harm the public interest and frustrate the aims of members of the public who have complied with property conventions in part to support this public good. This is one source of objections. Second, those who have entitlements to property under the old conventions might reasonably object that it is unfair to expropriate them even if some other convention might be preferable in the abstract. After all, they played by the rules as they existed at the time in reliance on being able to enjoy certain benefit. The extent to which existing entitlements should be preserved in a transition to a new convention is a difficult question that will turn on a wide range of factors. Among Humeans, those who develop Hume's insights in a contractarian direction are likely to differ on this point with those who use Hume's theory of justice as a foundation for a consequentialist political theory. But even on permissive understandings of fairness in transition, there will be many entitlements that ought to be respected as a matter of preserving social stability and dealing fairly with those who have done their part according to the rules as they were at the time.

It is unclear whether egalitarians are apt to disagree with this. But if the pragmatic reasons to adhere to existing property conventions are construed to include these considerations of fairness and public interest, one might wonder whether the objection boils down to a purely terminological dispute. On this interpretation, resource egalitarians and Humeans would agree that two sorts of normative considerations are important but disagree on whether to classify both as moral or to classify one as moral and one as pragmatic. I am inclined to find it peculiar to classify concerns that go to the heart of political order as pragmatic rather than moral, but the terminology may not matter much so long as both sides agree on what is normatively important.

A Humean analysis of the normative significance of property rights is not incompatible with retaining an important role for egalitarian theories. Resource egalitarian theories and Humean theories of property purport to be about the same subject- "justice"-but, properly understood, they play different roles. While Humean theory is primarily about the form and origin of property entitlements and only secondarily about their distribution, resource egalitarianism is primarily concerned with the distribution of property rights and only secondarily (if at all) with their form and origin. The most plausible syntheses of these theories would adopt a Humean view of property rights while analyzing certain other policy questions according to resource egalitarian standards. Humean property theory explains and justifies the normative authority of existing property rules and property entitlements in minimally decent and functional political orders. It also 
provides guidance as to how such rules can be revised under conditions characterized by limited altruism and moral disagreement. Resource egalitarian theories provide a framework to evaluate reform proposals. For example, if I am deciding whether to support a ballot measure increasing the minimum wage, I might decide how to vote by asking myself whether it increases the primary goods available to the least advantaged or whether it would increase aggregate utility. Once in the voting booth, I need not coordinate my activities with others, nor, given the small-bore nature of the proposal, worry much about destabilizing norms of cooperation between people with differing moral views. If, on the other hand, I am trying to decide whether it is just to comply with the actually prevailing property conventions and to respect entitlements that have arisen under them, egalitarian theory may give misleading advice if not tempered with Humean insights.

This analysis suggests a division of labor between the two types of theories. Humean theories address the justifiability of conventional norms such as those regulating basic property entitlements and political authority. Ideal theories of distributive justice may then be used to evaluate more finegrained questions of policy that are decided against the background of these conventional norms in contexts in which a single actor (usually the government) can simply impose its preferred rules. For this reason, the versions of resource egalitarianism that are most appealing for Humeans are those that yield metrics that score reform proposals as better or worse rather than determinate distributive principles that govern the basic structure as a whole, such as Dworkin's envy-free distribution of resources. The former include Sen's capabilities metrics, ${ }^{74}$ and, if it is considered to be a member of the category, utilitarianism.

\section{OBJECTIONS TO HUMEAN THEORY}

Hume's theory of justice is sometimes criticized as being too thin to justify strong moral entitlements as well as unduly conservative in its implications. My account of Humean property theory provides resources to reply to both claims. Some critics doubt that Humean theory can explain how property rights are full-bloodedly moral rights. For example, Jeremy Waldron doubts that "balance of power" reasoning can yield sufficient moral oomph to account for property rights. Waldron asserts that:

The Humean model is supposed to explain not only the emergence of a stable set of holdings, but also the emergence of property rights, and with a sense of rights a sense also of fairness and justice. But it is not at all clear that it can do that. No doubt some sense of an immutable balance of power might emerge from Humean negotiation, similar to the sense that characterizes

74. See Amartya Sen, The Idea of Justice (2009). 
international diplomacy. But why should we expect heavily moralized standards like justice and fairness-standards that connote the idea of the rightfulness of the proportion of one person's holding to another's-to emerge from the essentially amoral process that Hume and Buchanan describe? ${ }^{75}$

Waldron's worry is that although Hume's account may explain how property norms in the sense of behavioral regularities arise, it does not explain how property rights do so. His reference to the balance of power in international diplomacy is perhaps unintentionally apt. Customary international law is arguably another domain in which behavioral regularities that reflect balance of power logic become moralized over time. Of course, a stable balance of power only gives rise to entitlements backed by moralized norms under certain conditions. Conventions are apt to become moralized when they implicate important human interests and when the parties are not indifferent as to which rule is adopted.

The emergence of morally significant property rights from bare conventions is explained by the morality of fair play and the public interest in stable property conventions. When property norms first emerge, they are not moralized. They first appear as tentative expectations and then, as respect for others' possessions becomes more widespread, as a descriptive norm. That such norms reflect the balance of power between property claimants helps to create stable expectations about the behavior of others. Once settled expectations are in place, a sense of reciprocity may generate feelings of resentment against those who do not reciprocate respect for others' property. Respect for property rights becomes the new baseline for fair play. Violations of property rules are unfair because they involve taking advantage of the benefits of property rules while declining to share the burdens. This sort of blatant free riding is apt to draw moral disapproval from "conditional cooperators" even if property norms are not antecedently strongly moralized. People who violate the rules of mutually advantageous cooperative schemes for personal gain are apt objects of moral resentment much like cheaters and those who withhold their fair share of contributions to collective projects. In other contexts, one might worry about the fairness of enforcing the rules against those who have not consented to them. But property rules present a special case. Coordinating our use of property resources requires that all follow the same rules since it generally is not practical to exempt moral dissenters from compliance. Conventionally determined property rights do not have to conform to ideal principles of distributive justice to meet this standard. Because prospective violators cannot replace the existing convention with one they might prefer, but are only faced with the question of whether to comply or not, it is more appropriate to ask whether the prospective violator benefits from the enforcement of

75. Waldron, The Advantages and Difficulties of the Humean Theory of Property, supra note 3, at 115 . 
property rules more generally. Some distributions are so inequitable that there is little point in the "have-nots" respecting the property rights of the "haves" because their gains from compliance with property conventions are so negligible. The key is whether respect for the "balance of power" is advantageous for rich, poor, and those in between or whether the gains from cooperation accrue to only one of these groups. Where every individual shares to some extent in the gains from effective property conventions it is reasonable to hold each individual responsible for following the rules. Moralizing rules that reflect an approximate balance of power in situations fraught with the potential for destructive conflict helps to entrench stable equilibria and facilitates cooperation between people who may not agree on conceptions of equality or other potential foundations for property rights. That such norms reflect the "balance of power" rather than some abstract notion of human equality helps to foster stable relationships because it reduces the likelihood that people will violate social norms in hopes of getting a better deal with other partners or under different conventions.

In response to Waldron's reference to the "rightfulness of the proportion of one person's holding to another's," 76 Humeans will concede that property rights must be justified by reference to the justification of the conventional rules that create them rather than by direct consideration of the relation between one person's holdings and another's. But in this, Humean theory is not different from leading resource egalitarian views in which justification also proceeds via the outputs of institutions based on just principles rather than in terms of direct property holdings. Resource egalitarians might think that Humeans embrace the wrong institutions. But this is better framed as a disagreement about the substance of distributive justice than as a claim that Humean processes cannot yield moral entitlements. This account of the moralization of property norms is sufficient, I think, to address Waldron's worry. It requires a somewhat more precise theory of the principles of fair cooperation than that described by Hume. And it introduces some very minimal distributive considerations into Hume's theory. However, the claims that people are especially sensitive to "free riders" who fail to uphold cooperative schemes or reciprocate favors from others is both empirically plausible and consistent with what Hume does say about the moral psychology of justice. ${ }^{77}$

A second common criticism of Hume is that his theory of property is little more than rationalization of his deeply conservative political predilections

76. Id. at 115 .

77. A second and more ambitious way to respond to Waldron's concern about the role of balance of power logic in the Humean system is to appeal to recent neo-Humean theories of fairness. See Binmore, supra note 31; Binmore, supra note 46; Sugden, supra note 31 ; H. Peyton Young, Equity in Theory and Practice (1994); Nicolas Baumard, Jean-Baptiste André \& Dan Sperber, A Mutualistic Approach to Morality: The Evolution of Fairness by Partner Choice, 36 Behav. \& Brain Scis. 59 (2013). This approach is congruent with Hume's account of property rights, but requires the development of a broader political theory that is beyond the scope of this article. 
or, considered a bit more sympathetically, an important intellectual contribution that is limited by ideological prejudice. ${ }^{78}$ This perception is reinforced when figures such as Hayek claim Hume as an important forerunner. ${ }^{79}$ This is a threat to my defense of Humean property theory because part of the appeal of Humean theory is that it provides guidance in contexts where people disagree about principles of distributive justice. But if the Humean approach is irremediably tilted to "conservative" policy outcomes, then these purported advantages are illusory.

Using Hume's theory of property as a starting point to devise a more complete Humean political theory requires extending Humean analysis to questions that arise once a system of property rights is in place. Hume provided no analysis of how states might modify property rights beyond a fairly vague suggestion that the state sometimes must alter existing property rights to fit new circumstances. Hume approved, for example, of Henry VII's breaking of noble entails, a rather large change in property law. ${ }^{80}$ The challenge for Humean political theorists is to move beyond the sort of picture contemplated by Hume in the Treatise in which property rights, once established, are fairly static, and develop a theory under which Humean property rights constrain changes in property entitlements while allowing some scope for policies that alter property entitlements, impose taxes, and establish welfare and social insurance programs. Humean political theory takes rules of justice to approximate stable bargains between people with limited altruism and differing moral views but a willingness to adhere to mutually advantageous rules. Because Humean theory does not assume motivation to comply with rules of justice in absence of considerations of personal advantage, Humean rules of justice must be calculated to appeal to actual persons, not their idealized selves stripped of purportedly biasing characteristics. Once fundamental conventions of property, contract, and allegiance to the state are in place, Humean theory evaluates further rules against the background of the existing social contract in light of their stability, efficiency, and fairness. Fundamental conventions constrain policy options while still leaving some flexibility. ${ }^{81}$ Because Humean theory takes the existing social contract as the starting point for reform, ${ }^{82}$ considerations of fairness and utility may favor different reforms in different contexts.

78. E.g., BARrY, supra note 3, at 164 .

79. E.g., Friedrich A. Hayek, Law, Liberty and Legislation, Volume 1: Rules and Order (1973), at 6 .

80. See SABL, supra note 26, at 67-69, 235.

81. Elsewhere, I have argued that Humean considerations counsel in favor of horizontal equity in taxation, the principle that persons with the same income should pay the same amount of tax. Ira K. Lindsay, Tax Fairness by Convention: A Defense of Horizontal Equity, 19 FLA. TAx Rev. 79 (2016). This position is neutral on the question of whether tax rates should be progressive so as to require relatively greater contributions from those with more income or proportionate contributions.

82. David Hume, Idea of a Perfect Commonwealth, in David Hume: Political Essays 221 (Knut Haakonssen ed., 1994). 
An analogy to the rule of law might help illustrate the significance of property rights. Rule by law (rather than by personal command, decree, or whim), requires that government officials attach a great deal of importance to what the law tells them regardless of its contents. Frequent, serious violations of law by officials undermine trust and encourage others to ignore the law. If one's political rivals do not follow the law, it is hard to see why one should sacrifice one's own interests or normative principles in order to do so. In general, therefore, government officials ought to follow the law even when they have reasons not to. The rule of law is not, however, always a decisive consideration. In exceptional circumstances, officials ought to violate the law to serve some other end. Just as large-scale cooperation between people with differing political views requires that people usually follow laws that they do not favor, cooperation often requires deference to conventional property entitlements. Under normal circumstances, officials should respect existing property rights. Expropriations of property owners undermine the conventional foundations of political order and thus should be disfavored. Like the rule of law, respect for existing property entitlements is extremely important, but it does not always outweigh all other considerations. In exceptional cases, circumstances might require violation of existing entitlements or redefinition of property rights. Humeans will always disfavor such measures, although, like violations of the rule of law, they are occasionally necessary. Left-leaning and right-leaning Humeans are likely to disagree about where to draw the line between normal and exceptional cases, but agree on the sort of considerations that are relevant in deciding how to do so.

There is thus a sense in which Humean theories are unquestionably small "c" conservative: existing property conventions are entitled to deference on account of the advantages of stability. However, this point seems to apply equally well to market socialist arrangements as to "nightwatchman state" property regimes. Humean political theory is therefore not necessarily conservative in the ideological sense of the term, but rather can be developed in both "left" and "right" directions. Conservative Humean political thought is concerned with the preservation of social order against the twin dangers of anarchy and governmental predation. It favors a classically liberal political order so as to prevent wasteful conflict over resources and secure broad freedoms for property owners to use their property as they see fit. Unlike neo-Lockeans, however, Humean conservatives such as Friedrich Hayek and James Buchanan do not see classically liberal property rights as protecting the pre-institutional moral entitlements of property owners.

Although conservative Humeans are the best-known representatives of the Humean tradition, Humean insights can be developed in directions more congenial to modern liberalism as well. There are several ways for leftleaning Humeans to argue that a Humean framework is consistent with, or even requires, significantly redistributive government policies. First, the Humean emphasis on the importance of long-term mutual advantage 
constrains the sort of inequality that is possible in a stable property regime. Stable conventions require that even those who are relatively disadvantaged receive enough that they are better off not violating the convention. Even people who make little material contribution may therefore be entitled to share in the gains of cooperation to a considerable extent if their respect for property conventions allows others to be productive. ${ }^{83}$ Balance of power logic, therefore, does not necessarily support a laissez-faire attitude toward market outcomes especially with respect to those who fare poorly in the market. Property conventions that deny some people the possibility of benefiting from property ownership while requiring them to obey rules of justice will tend not to be self-enforcing because a significant part of the population will not see adherence to property rules as in its longrange self-interest. This provides reason to reject rules that generate huge structural inequalities such that a significant portion of the population does not own property, cannot reasonably aspire to acquire any, and earns only enough to meet basic survival needs. And it serves to rule out types of status inequality that are incompatible with a sense of common interest in the stability of a property regime. Such rules may be maintained by force. But by blocking any appeal to natural rights, Humean theory provides no reason to think that massive coercion is justified under normal circumstances.

So far this argument only suggests that there is a strong case for benefits to the poor that go well beyond the subsistence minimum. When one turns to the question of how to divide the gains from cooperation above the subsistence minimum, a conventionalist approach that analyzes justice as mutual advantage may imply outcomes that are more egalitarian than those endorsed by conservative Humeans. ${ }^{84}$ Ken Binmore has argued that something akin to Rawlsian substantive principles can be defended using game theory to model the behavior of rational self-interested agents. ${ }^{85}$ Binmore's basic insight is that bargains between self-interested parties that provide relatively more to the least advantaged parties tend to be uniquely stable because such bargains minimize incentives to undermine the agreement in hopes of getting a better deal in the future. ${ }^{86}$ This has two important implications. First, there is reason to expect division of gains from cooperation to systematically deviate from utilitarian prescriptions in an egalitarian direction. Second, successive renegotiations of the social contract in response to new circumstances will distribute benefits widely in order to secure agreement. Each movement to a new equilibrium will

83. James M. Buchanan, The Limits of Liberty (2000), at 80-82.

84. This approach to justice as mutual advantage is deeply controversial and may, of course, be rejected by many who favor Humean approaches to property. The point here is merely that it is a possible way of developing Humean insights in a more egalitarian direction.

85. See Binmore, supra note 31, 41-49, 52-53.

86. The technical details differ a fair bit from Rawls's maximin principle. 
involve a different division of the gains so that people who received less from the last renegotiation might receive more from the next.

Second, in many circumstances, the long-run interests of the powerful are not well served by widespread poverty. This suggests that effective antipoverty programs have the potential to be win-win outcomes for rich and poor. Large impoverished populations are a drag on economic growth. Poverty and low productivity form a vicious cycle: low-productivity workers are likely to be poor and the poor may be unable to make investments that would make them more productive. High productivity workers, by contrast, benefit their fellow citizens through their increased purchasing power, ability to support public goods through higher tax payments, and, under some conditions, through returns to scale in combining the labor of high productivity workers. Moreover, countries with large masses of poor people tend to be less pleasant to live in even for the relatively well off. It is in nearly everyone's long-term interest that productive (or potentially productive) members of the community have enough resources to reach their economic potential. In very poor countries, this may mean that state intervention is justified in order to ensure that the poor have enough food to work effectively. ${ }^{87}$ In wealthier countries, support for the economically disadvantaged may include access to free education and training. These considerations suggest that there are usually ways to structure such transfers from rich to poor that are mutually beneficial at least when considering the interests of the wealthy over the very long run (including their interest in the welfare of their descendants). A fair amount of such support may be justified as public investment rather than in terms of distributive fairness. Insofar as such resource transfers benefit the public generally, the less advantaged may be at a baseline considerably above subsistence before consideration of how to divide the cooperative surplus.

Third, Humean property rights are consistent with robust social insurance. Social insurance, broadly construed, consists in the pooling of risk so as to mitigate the effects of various misfortunes that may befall individuals in the course of their lifetime. These include illness, disability, premature death (i.e., losing one's parents at a young age), poverty of extreme old age (i.e., outliving one's assets), involuntary unemployment, economic bad luck of various kinds, and natural disasters, among other misfortunes. Social insurance includes programs explicitly structured as such (i.e., social security and unemployment insurance) as well as various programs that are primarily directed at other ends but have a social insurance component as well (i.e., income taxation, public education). Social insurance programs are redistributive ex post because they collect taxes from all to pay benefits to the unfortunate. Ex ante, however, they might be in the interest of all because each person receives compensation in the form of insurance for

87. For workers engaged in heavy physical labor this goes far beyond the subsistence minimum. 
the payments that they make in taxes. Because social insurance schemes involve an implicit forced purchase of insurance (whether or not the taxpayer wants it), neo-Lockeans sometimes find them objectionable. From a Humean perspective, pure social insurance is unexceptionable. Just as people are justly required to respect the property rights of others so that all can enjoy the systematic benefits of stable property entitlements, all people may be compelled to contribute to a social insurance scheme so that all may enjoy its benefits. ${ }^{88}$ Humeans may thus appeal to social insurance as a way to achieve a more egalitarian distribution of income without disrupting existing property entitlements. The extent to which redistributive insurance schemes can be justified within a Humean framework is complicated because it depends crucially on the baseline used to assess redistribution and on conjectures about risk aversion. There is plenty of scope for disagreement between left-leaning and right-leaning Humeans on this point. My point here is only that left-leaning policy preferences are not ruled out by the use of a Humean framework.

\section{CONCLUSION}

Humean property theory combines a plausible account of the nature and origins of property rights with an argument for taking property rights seriously. It emphasizes the normative significance of property conventions without moralizing property relations to the extent that neo-Lockeans and resource egalitarians each do in different ways. Treating existing property entitlements as having prima facie validity facilitates cooperation between people who disagree about distributive justice. The relative modesty of Humean theory allows Humeans to ascribe moral significance to the outcomes of historical processes without endorsing the often dubious ways in which property was originally acquired. And it leaves some scope for public policy that influences future distributions of property. Humean property rights are consistent with a range of political views so long as they share a modest liberalism about the benefits of private property and a modest conservativism about the benefits of social stability. I have tried to present a rather broad-brush account of Humean property theory that can be embraced by Humeans of all stripes. A complete Humean political theory requires taking stances on hard questions concerning the moral psychology of social cooperation, the role of fairness considerations in distributive justice, and the ways in which the state may alter existing property entitlements. Hume's theory of property does not provide complete answers to all of these questions but does provide a promising framework for analyzing them.

88. Hume makes clear that governments can play an important role in solving the collective action problem inherent in the provision of public goods. See Hume, supra note 25, at $\$ 7,538$ 539. 